\title{
Effect of tolerance to paternal antigens on placental and fetal weight in the mouse
}

\author{
C. M. Hetherington and Helen Fowler \\ Clinical Research Centre, Watford Road, Harrow, Middlesex HA1 3UJ, U.K.
}

\begin{abstract}
Summary. Placental and fetal weight was measured on the 16 th day of pregnancy in normal and tolerant mice. Placental weight was increased in A mice tolerant to C57BL/ 10 mice only when donor cells from males were used. Fetal weight was unaffected.
\end{abstract}

\section{Introduction}

James (1965, 1967) has reported that the fetuses and placentae of C57BL female mice rendered tolerant to the antigens of $A 2 G$ mice and then mated to $A 2 G$ males were lighter than those of normal females. The data of Beer, Scott \& Billingham (1975), from a study of placental weight involving A females tolerant of C57BL antigens, $\mathrm{CBA}$ females tolerant of $\mathrm{C} 3 \mathrm{H}$ antigens and $\mathrm{C} 3 \mathrm{H}$ females tolerant of CBA antigens, confirmed those of James. Clarke (1971), however, was unable to repeat the work of James $(1965,1967)$ because tolerance in C57BL mice to A2G antigens could not be induced, most of the mice dying from runt disease. A2G mice are closely related to A mice (Clarke, 1973) and it has been reported that C57BL mice cannot be rendered tolerant of $\mathrm{A}$ antigens (Billingham \& Brent, 1959; Boyse, Lance, Carewell, Cooper \& Old, 1970; Silvers, Wachtel \& Poole, 1976). In this and other strain combinations injections of neonates result in graft-versus-host disease and splenomegaly (Simpson et al., 1974).

In the experiments of James $(1965,1967)$ and Beer et al. $(1975)$ there were no non-specific controls to determine whether the induction of tolerance to one mouse strain affected fetal weight, placental weight or litter size when tolerant animals were mated with animals of a strain to which they had not been rendered tolerant. Animals which have received injections neonatally might, for instance, be suffering from subclinical graft-versus-host disease. Also, there was little or no consideration of litter size which is known to affect fetal and placental weight in mice (Healy, McLaren \& Michie, 1960).

The experiments reported here were designed to test the findings of James $(1965,1967)$ that placental and fetal weight in mice tolerant of the antigens of the stud male are reduced due to the failure of the mother to recognize as foreign the paternal antigens present in the fetus.

\section{Materials and Methods}

The mouse strains used, A/Crc $\left(\mathrm{H}-2^{a}\right), \mathrm{C} 57 \mathrm{BL} / 10 / \mathrm{Crc}\left(\mathrm{H}-2^{\mathrm{b}}\right), \mathrm{CBA} / \mathrm{CaCrc}\left(\mathrm{H}-2^{\mathrm{k}}\right)$ and $\mathrm{C} 3 \mathrm{H} / \mathrm{HeCrc}$ $\left(\mathrm{H}-2^{\mathbf{k}}\right)$, were bred at the Clinical Research Centre and are subsequently referred to as A, B10, CBA and $\mathrm{C} 3 \mathrm{H}$ strains. The health status of these animals was at least equivalent to category 4 of the Medical Research Council Laboratory Animals Centre, Animal Breeders Accreditation Scheme (Townsend, 1969). Mice of strain A were rendered tolerant to the antigens of B10 by the injection of $40 \times 10^{6}$ spleen cells from male or female $(\mathrm{B} 10 \times \mathrm{A}) \mathrm{F} 1$ mice into the anterior facial vein within $24 \mathrm{~h}$ of birth. CBA mice were similarly injected with cells fren $(\mathrm{CBA} \times \mathrm{C} 3 \mathrm{H}) \mathrm{F} 1$ males. Tolerance was confirmed by grafting, at 4 to 5 weeks of age, with tail skin of mice of the relevant strain and sex: only those animals bearing grafts were used in the tolerant groups.

Mice were mated at 8 weeks of age. Normal and tolerant A females were mated to B10 or CBA males. Normal and tolerant $\mathrm{CBA}$ females were mated to $\mathrm{C} 3 \mathrm{H}$ males. The day of finding the vaginal plug was designated Day 1 of pregnancy and all mice were killed by cervical dislocation on Day 16. Placentae and fetuses were removed from the uterus, blotted lightly and weighed. The number of 
live fetuses and the number of conceptuses dying during early, middle and late pregnancy was recorded according to the method of McLaren \& Michie (1959). The sum of live conceptuses and those dying in middle and late pregnancy is referred to as 'litter size'. The weights of the inguinal and renal plus lumbar lymph nodes and spleen were recorded.

The mean placental and fetal weights for each female were calculated. The means were not weighted according to the number of conceptuses present because variation within a uterus tends to rise as the number of conceptuses increases, and the amount of information from the mean does not therefore depend very greatly on the number of fetuses (Healy et al., 1960). Placental and fetal weights were analysed by the regression of $\log _{10}$ mean placental weight and $\log _{10}$ mean fetal weight on litter size (as defined above), a method which has been shown to be appropriate by Healy et al. (1960). Differences in placental or fetal weights between groups were compared by using the $\log _{10}$ means adjusted to the overall mean litter size by means of the pooled within-group regression coefficients. A logarithmic transformation was used as the variance of placental and fetal weight is proportional to the mean. Spleen and lymph node weights were analysed by Student's $t$ test with a $\log _{10}$ transformation.

\section{Results}

The regressions of $\log _{10}$ mean placental weight and $\log _{10}$ mean fetal weights on litter size did not differ in slope within each experiment. The adjusted mean placental weight in A females tolerant of and mated to B10 males was significantly greater than in normal A mice mated to B10 males $(P<0.01$; Table 1). There was no difference between the adjusted mean placental weights in normal and tolerant A mice when they were mated to CBA males. Spleen weight was significantly greater in A mice tolerant of $\mathrm{B} 10$ animals $(P<0.05)$; lymph node weight also tended to be larger but the increase was not significant. Litter size was significantly greater in A females mated to CBA males than in those mated to B10 males.

When the data on tolerant A mice were analysed according to the sex of the donor, it was found that, within the group mated to B10 males, placental weight was significantly greater in the animals receiving cells from a male donor. The placental weight in animals injected with cells from a female donor was greater than, but not significantly different from, placental weight in the control group (Tables 1 and 2). There was no similar effect of the sex of donor on placental weight when tolerant $\mathbf{A}$

Table 1. The mean \pm s.e.m. litter size and weight $(\mathrm{mg})$ of placentae, fetuses, spleen and lymph nodes in normal and tolerant mice

\begin{tabular}{|c|c|c|c|c|c|c|c|c|c|}
\hline \multirow[b]{2}{*}{$\begin{array}{l}\text { Strain } \\
\text { of } \\
\text { dam }\end{array}$} & \multirow[b]{2}{*}{$\begin{array}{l}\text { Immune } \\
\text { status }\end{array}$} & \multirow[b]{2}{*}{$\begin{array}{c}\text { Strain } \\
\text { of } \\
\text { sire }\end{array}$} & \multirow[b]{2}{*}{$\begin{array}{l}\text { No. } \\
\text { of } \\
\text { mice }\end{array}$} & \multirow[b]{2}{*}{$\begin{array}{l}\text { Placental } \\
\text { wt }\end{array}$} & \multirow[b]{2}{*}{$\begin{array}{c}\text { Fetal } \\
\text { wt }\end{array}$} & \multirow[b]{2}{*}{$\begin{array}{l}\text { Spleen } \\
\text { wt }\end{array}$} & \multicolumn{2}{|c|}{ Lymph node wt } & \multirow[b]{2}{*}{$\begin{array}{l}\text { Litter } \\
\text { size }\end{array}$} \\
\hline & & & & & & & $\begin{array}{c}\text { Lumbar } \\
\text { and } \\
\text { renal }\end{array}$ & Inguinal & \\
\hline A & Control & B10 & 13 & $\begin{array}{c}110.4 \pm \\
6.2\end{array}$ & $\begin{array}{c}342 \cdot 4 \pm \\
18 \cdot 0\end{array}$ & $\begin{array}{c}145 \cdot 7 \pm \\
8 \cdot 7\end{array}$ & $\begin{array}{l}9 \cdot 9 \pm \\
1.9\end{array}$ & $\begin{array}{l}6.7 \pm \\
0.8\end{array}$ & $\begin{array}{l}5.3 \pm \\
0.7\end{array}$ \\
\hline A & $\begin{array}{r}\text { Tolerant } \\
\text { of } B 10\end{array}$ & B10 & 11 & $\begin{array}{c}133 \cdot 6 \pm \\
6 \cdot 0^{*}\end{array}$ & $\begin{array}{c}379 \cdot 6 \\
12 \cdot 1\end{array}$ & $\begin{array}{c}305 \cdot 2 \pm \\
66 \cdot 8^{*}\end{array}$ & $\begin{array}{c}11.4 \pm \\
1.9\end{array}$ & $\begin{array}{l}8.8 \pm \\
1.3\end{array}$ & $\begin{array}{l}4.4 \pm \\
0.8\end{array}$ \\
\hline A & Control & CBA & 15 & $\begin{array}{c}88 \cdot 3 \pm \\
2 \cdot 4\end{array}$ & $\begin{array}{c}311.8 \pm \\
9.5\end{array}$ & $\begin{array}{c}127 \cdot 0 \pm \\
0.7\end{array}$ & $\begin{array}{c}11.3 \pm \\
0.7\end{array}$ & $\begin{array}{l}7 \cdot 2 \pm \\
0.6\end{array}$ & $\begin{array}{l}9.7 \pm \\
0.7\end{array}$ \\
\hline A & $\begin{array}{r}\text { Tolerant } \\
\text { of } \mathrm{B} 10\end{array}$ & CBA & 12 & $\begin{array}{c}90 \cdot 3 \pm \\
3 \cdot 1\end{array}$ & $\begin{array}{c}294.7 \pm \\
9.6\end{array}$ & $304 \cdot 4 \pm$ & $\begin{array}{c}14 \cdot 3 \pm \\
2 \cdot 4\end{array}$ & $\begin{array}{l}7 \cdot 6 \pm \\
1 \cdot 1\end{array}$ & $\begin{array}{l}8 \cdot 7 \pm \\
0.6\end{array}$ \\
\hline $\mathrm{C} 3 \mathrm{H}$ & Control & CBA & 12 & $\frac{98 \cdot 1}{2 \cdot 6} \pm$ & $\begin{array}{c}319.3 \pm \\
6.1\end{array}$ & $\begin{array}{c}169 \cdot 4 \pm \\
6.7\end{array}$ & $\begin{array}{c}13.3 \pm \\
0.7\end{array}$ & $\begin{array}{c}10.0 \pm \\
0.7\end{array}$ & $\begin{array}{l}8 \cdot 8 \pm \\
0 \cdot 3\end{array}$ \\
\hline $\mathrm{C} 3 \mathrm{H}$ & $\begin{array}{l}\text { Tolerant } \\
\text { of CBA }\end{array}$ & CBA & 10 & $\begin{array}{c}102 \cdot 6 \pm \\
2 \cdot 8\end{array}$ & $\underset{8.4}{324.5} \pm$ & $\begin{array}{c}171 \cdot 7 \pm \\
3.8\end{array}$ & $\begin{array}{c}13.7 \pm \\
0.9\end{array}$ & $\begin{array}{c}11.2 \pm \\
0.6\end{array}$ & $\begin{array}{l}8.0 \pm \\
0.3\end{array}$ \\
\hline
\end{tabular}


Table 2. Mean \pm s.e.m. litter size and weight $(\mathrm{mg})$ of placentae, fetuses, spleen and lymph nodes in $A$ mice injected neonatally with cells from male or female Fl mice

\begin{tabular}{|c|c|c|c|c|c|c|c|c|}
\hline \multirow[b]{2}{*}{$\begin{array}{l}\text { Sex of } \\
\text { donor of } \\
\text { cells }\end{array}$} & \multirow[b]{2}{*}{$\begin{array}{l}\text { Strain of } \\
\text { sire }\end{array}$} & \multirow[b]{2}{*}{$\begin{array}{l}\text { No. } \\
\text { of } \\
\text { mice }\end{array}$} & \multirow[b]{2}{*}{$\begin{array}{c}\text { Placental } \\
\text { wt }\end{array}$} & \multirow[b]{2}{*}{$\begin{array}{c}\text { Fetal } \\
\text { wt }\end{array}$} & \multirow[b]{2}{*}{$\begin{array}{c}\text { Spleen } \\
\text { wt }\end{array}$} & \multicolumn{2}{|c|}{ Lymph node wt } & \multirow[b]{2}{*}{$\begin{array}{l}\text { Litte } \\
\text { size }\end{array}$} \\
\hline & & & & & & $\begin{array}{l}\text { Lumbar } \\
\text { and } \\
\text { renal }\end{array}$ & Inguinal & \\
\hline Male & B10 & 4 & $\begin{array}{c}150.9 \pm \\
7.9 *\end{array}$ & $\underset{17.5}{401.2} \pm$ & $\begin{array}{c}189 \cdot 7 \pm \\
41 \cdot 1^{*}\end{array}$ & $\underset{2 \cdot 8}{11 \cdot 8 \pm}$ & $\begin{array}{l}8 \cdot 3 \pm \\
1.9\end{array}$ & $\begin{array}{l}3.3 \pm \\
1.6\end{array}$ \\
\hline Female & B10 & 7 & $\begin{array}{c}123.7 \\
5.7\end{array}$ & $\begin{array}{c}367.2 \pm \\
15.2\end{array}$ & $\begin{array}{c}371.3 \pm \\
95.9\end{array}$ & $\begin{array}{c}10.5 \pm \\
2.6\end{array}$ & $\begin{array}{l}9 \cdot 1 \pm \\
1 \cdot 9\end{array}$ & $\begin{array}{l}5.0 \pm \\
0.9\end{array}$ \\
\hline Male & $\mathrm{CBA}$ & 5 & $\begin{array}{c}86.5 \pm \\
5.0\end{array}$ & $\begin{array}{c}283.5 \pm \\
11.4\end{array}$ & $\begin{array}{c}251.9 \pm \\
59.9^{*}\end{array}$ & $\begin{array}{c}13.6 \pm \\
2 \cdot 3\end{array}$ & $\begin{array}{l}8 \cdot 5 \pm \\
2 \cdot 1\end{array}$ & $\begin{array}{l}9.7 \pm \\
0.7\end{array}$ \\
\hline Female & $\mathrm{CBA}$ & 7 & $\begin{array}{c}92.9 \pm \\
3.8\end{array}$ & $\begin{array}{c}302 \cdot 7 \\
14 \cdot 2\end{array}$ & $\begin{array}{c}342 \cdot 0 \pm \\
37.7\end{array}$ & $\begin{array}{c}14.7 \pm \\
3.9\end{array}$ & $\begin{array}{l}6.9 \pm \\
1.2\end{array}$ & $\begin{array}{l}8.0 \pm \\
1.0\end{array}$ \\
\hline
\end{tabular}

* Value significantly different from that of animals receiving donor cells from the opposite sex, $P<0.05$.

Table 3. Partial regressions of fetal weight $(\mathrm{mg})$ on litter size, placental weight $(\mathrm{mg})$ and spleen weight (mg)

\begin{tabular}{lllllc}
\hline $\begin{array}{c}\text { Strain } \\
\text { of dam }\end{array}$ & Immune status & $\begin{array}{c}\text { Strain } \\
\text { of sire }\end{array}$ & Litter size & Placental wt & Spleen wt \\
\hline A & Control & B10 & $\mathbf{0 . 0 1 1 \pm 0 . 0 1 4}$ & $0.915 \pm 0.408^{*}$ & $-0.577 \pm 0.242^{*}$ \\
A & Tolerant of B10 & B10 & $-0.008 \pm 0.008$ & $0.029 \pm 0.327$ & $-0.068 \pm 0.045$ \\
A & Control & CBA & $-0.003 \pm 0.004$ & $0.812 \pm 0.215^{* *}$ & $-0.133 \pm 0.085$ \\
A & Tolerant of B10 & CBA & $-0.004 \pm 0.008$ & $0.200 \pm 0.344$ & $0.050 \pm 0.082$ \\
C3H & Control & CBA & $-0.004 \pm 0.008$ & $0.508 \pm 0.188^{*}$ & $0.077 \pm 0.118$ \\
C3H & Tolerant of CBA & CBA & $-0.002 \pm 0.013$ & $0.390 \pm 0.422$ & $0.344 \pm 0.588$ \\
\hline
\end{tabular}

Values are coefficient \pm s.e. of the $\log _{10}$ weights.

Significant regression coefficient, ${ }^{*} P<0.05,{ }^{* *} P<0.01$.

Table 4. Partial regressions of placental weight $(\mathrm{mg})$ on litter size, fetal weight $(\mathrm{mg})$ and spleen weight (mg)

\begin{tabular}{lllllr}
\hline $\begin{array}{c}\text { Strain } \\
\text { of dam }\end{array}$ & Immune status & $\begin{array}{c}\text { Strain } \\
\text { of sire }\end{array}$ & Litter size & Fetal wt & Spleen wt \\
\hline A & Control & B10 & $-0.022 \pm 0.006^{* *}$ & $0.392 \pm 0.175^{*}$ & $0.301 \pm 0.176$ \\
A & Tolerant of B10 & B10 & $-0.019 \pm 0.007^{*}$ & $0.039 \pm 0.437$ & $0.004 \pm 0.060$ \\
A & Control & CBA & $-0.003 \pm 0.004$ & $0.696 \pm 0.184^{* *}$ & $0.126 \pm 0.078$ \\
A & Tolerant of B10 & CBA & $-0.009 \pm 0.008$ & $0.203 \pm 0.349$ & $-0.040 \pm 0.084$ \\
C3H & Control & CBA & $0.004 \pm 0.010$ & $0.937 \pm 0.348^{*}$ & $-0.040 \pm 0.164$ \\
C3H & Tolerant of CBA & CBA & $0.003 \pm 0.012$ & $0.319 \pm 0.346$ & $0.807 \pm 0.437$ \\
\hline
\end{tabular}

Values are coefficient \pm s.e. of the $\log _{10}$ weight.

Significant regression coefficient, ${ }^{*} P<0.05,{ }^{* *} P<0.01$.

mice were mated to CBA males. Spleen weight was significantly greater in A mice injected with cells from a female donor than in those injected with cells from a male donor in animals mated to B10 and CBA males. There were no significant differences in other measurements between animals receiving cells from male and female donors.

No significant differences were found between normal $\mathrm{C} 3 \mathrm{H}$ mice and $\mathrm{C} 3 \mathrm{H}$ mice tolerant of $\mathrm{CBA}$ in any of the measurements made.

Litter size tended to be smaller in tolerant animals of all groups, but the reduction was not significant.

A partial regression analysis was carried out to determine whether splenomegaly affected either placental or fetal weight. The independent effect of spleen weight on fetal weight and placental weight 
within each group is shown in Tables 3 and 4 respectively. The regression of spleen weight on fetal weight was negative in three of the groups but significant in only one of these (normal A mated to $\mathrm{B} 10$ ). The effect of spleen weight on placental weight was negative in 2 groups and significant in none.

\section{Discussion}

In direct contrast to the experiments of James $(1965,1967)$ and Beer et al. (1976) placental weight in the present study was significantly greater in A mice tolerant of and mated to B10 males than in controls. This effect was specific in that placental weight of tolerant A mice did not differ from that of controls when mated to CBA males. It is apparent that the effect on placental weight in the present study was restricted to those animals receiving cells from a male donor: neither James $(1965,1967)$ nor Beer et al. (1975) reported the sex of the donor of the cells used for neonatal injections.

James $(1965,1967)$ found that fetal and placental weight were reduced in tolerant animals, in our study fetal weight was unaffected, and, in contrast, Beer et al. (1975) found that fetal weight was increased in the 2 experiments in which it was measured. The increase in tolerant animals was probably significant in one of these experiments but the authors make no comment. It is possible that the absence of non-specific controls in the work of James and Beer et al. caused the difference in results of these studies. Simpson et al. (1974) reported that mice receiving neonatal injections to induce tolerance went through two periods of runting, the first at 2 weeks of age and the second between 5 and 7 weeks of age. The animals used by James and Beer et al. may have been passing through a runting phase which would have caused poor health and consequent reduced placental weight, and perhaps also the reduction in lumbar and renal lymph node weight reported by Beer et al. (1975). In the present study lymph node weight was not affected significantly although weights were greater in all tolerant groups.

The reason for splenomegaly in A mice tolerant of B10 skin is not known. It is possible that the animals, although tolerant of skin alloantigens, were experiencing a graft-versus-host reaction related to other alloantigenic determinants. This would not explain, however, why splenomegaly was greater in animals receiving cells from female donors than in those receiving cells from male donors. It is probable that the absence of splenomegaly in CBA mice tolerant of $\mathrm{C} 3 \mathrm{H}$ is due to the close genetic relationship between these two strains (Strong, 1942).

The present study does not confirm the original report of James $(1965,1967)$ that placental and fetal weights are reduced in female mice tolerant of paternal antigens. Further experiments are required to determine whether the increase in placental weight reported here has an immunological basis.

We are grateful to Dr A. McLaren F.R.s. and Dr A. Clarke for their critical appraisal of the manuscript.

\section{References}

Beer, A.E., Scott, J.R. \& Billingham, R.E. (1975) Histocompatibility and maternal immunological status as determinants of fetoplacental weight and litter size in rodents. J. exp. Med. 142, 180-196.

Billingham, R.E. \& Brent, L. (1959) Quantitative studies on tissue transplantation immunity. Phil. Trans. R. Soc. B 242, 439-477.

Boyse, E.A., Lance, E.M., Carswell, E.A., Cooper, S. \& OLD, L.J. (1970) Rejection of skin allografts by radiation chimeras: selective gene action in the specification of cell surface structure. Nature, Lond. 227, 901-903.

Clarke, A.G. (1971) The effects of maternal pre-im- munisation on pregnancy in the mouse. $J$. Reprod. Fert. 24, 369-375.

Clarke, A.G. (1973) Studies on immunological interaction between mother and foetus. Ph.D. thesis, University of Edinburgh.

Healy, M.J.R., Mclaren, A. \& Michie, D. (1960) Fetal growth in the mouse. Proc. R. Soc. B 153, 367379.

JAMES, D.A. (1965) Effects of antigenic dissimilarity between mother and foetus on placental size in mice. Nature, Lond. 205, 613-614.

JAMES, D.A. (1967) Some effects of immunological factors on gestation in mice.J. Reprod. Fert. 14, 265-275. 
McLaReN, A. \& Michie, D. (1959) Superpregnancy in the mouse. 1. Implantation and foetal mortality after induced superovulation in females of various ages. J. exp. Biol. 36, 281-300.

Silvers, W.K., WAChTel, S.S. \& POOLE, T.W. (1976) The behaviour of skingrafts incompatible with respect to skin alloantigens on mice rendered tolerant at birth with lymphoid cells. J. exp. Med. 143, 1317-1326.
Simpson, E., O'Hopp, S., Harrison, M., Mosier, D., Melief, K. \& Cantor, H. (1974) Immunological disease induced by injecting $\mathrm{F} 1$ lymphoid cells into certain parental strains.-Immunology 27, 989-1007.

Strong, L.C. (1942) The origin of some inbred mice. Cancer Res. 2, 531-539.

TownSEND, G.H. (1969) The grading of commercially bred laboratory animals. Vet. Rec. 85, 225-226.

Received 20 May 1977 